\title{
The androgen receptor as an emerging target in hepatocellular carcinoma
}

\author{
This article was published in the following Dove Press journal: \\ Journal of Hepatocellular Carcinoma \\ 26 June 2015 \\ Number of times this article has been viewed
}

\section{Tatsuo Kanda \\ Osamu Yokosuka}

Department of Gastroenterology and Nephrology, Chiba University, Graduate School of Medicine, Chiba, Japan
Correspondence: Tatsuo Kanda

Department of Gastroenterology and

Nephrology, Chiba University, Graduate

School of Medicine, I-8-I Inohana,

Chuo-ku, Chiba 260-8670, Japan

Tel +8I 432262086

Fax $+8 \mid 432262088$

Email kanda2t@yahoo.co.jp
Abstract: Hepatocellular carcinoma (HCC) is one of the male-dominant liver diseases with poor prognosis, although treatments for HCC have been progressing in the past decades. Androgen receptor (AR) is a member of the nuclear receptor superfamily. Previous studies reported that AR was expressed in human HCC and non-HCC tissues. AR is activated both ligand-dependently and ligand-independently. The latter is associated with a mitogen-activated protein kinase-, v-akt murine thymoma viral oncogene homolog 1-, or signal-transducer and activator of transcription-signaling pathway, which has been implicated in the development of HCC. It has been reported that more than 200 RNA expression levels are altered by androgen treatment. In the liver, androgen-responsive genes are cytochrome P450s, transforming growth factor $\beta$, vascular endothelial growth factor, and glucose-regulated protein $78 \mathrm{kDa}$, which are also associated with human hepatocarcinogenesis. Recent studies also revealed that AR plays a role in cell migration and metastasis. It is possible that cross-talk among AR-signaling, endoplasmic reticulum stress, and innate immune response is important for human hepatocarcinogenesis and HCC development. This review shows that AR could play a potential role in human HCC and represent one of the important target molecules for the treatment of HCC.

Keywords: vascular endothelial growth factor, angiogenesis, glucose-regulated protein $78 \mathrm{kDa}$, hepatocarcinogenesis, molecular targets

\section{Introduction}

Hepatocellular carcinoma (HCC) is one of the male-dominant cancers with poor prognosis, although treatments are being developed. ${ }^{1-4} \mathrm{HCC}$ usually occurs after the age of 40 years, reaching a peak at approximately 70 years of age. ${ }^{5}$ Irrespective of their etiology, rates of HCC among men are two to four times higher than those among women. ${ }^{5} \mathrm{HCC}$ derived from hepatitis B virus (HBV) or hepatitis $\mathrm{C}$ virus infection and virus-unrelated HCC are male-dominant disorders. ${ }^{6,7}$ Similar sex difference is also observed in mice given a chemical carcinogen, diethylnitrosamine. ${ }^{8}$

In humans, androgen and estrogen are essential sex steroid hormones involved in many cellular processes such as cell metabolism and cell differentiation, as well as sex development. ${ }^{9}$ Both androgen receptor (AR) and estrogen receptor $\alpha$, for androgen and estrogen, respectively, seem to be involved in hepatocellular carcinogenesis. ${ }^{8,10-12}$ There have been many reports concerning the expression of AR in HCC and its surrounding liver tissues. ${ }^{13-31}$ The association between AR and liver diseases is shown in Table 1. In this review article, we provide comprehensive insights regarding the association between ARs and HCC. We have been expecting that AR would become an emerging therapeutic target in HCC. 
Table I Androgen receptor (AR) and liver diseases from different etiologies

\begin{tabular}{lll}
\hline $\begin{array}{l}\text { Etiology } \\
\text { of HCC }\end{array}$ & Roles of AR & References \\
\hline HBV & $\begin{array}{l}\text { AR-CAG repeats may be associated } \\
\text { with an increased risk of HCC }\end{array}$ & 116 \\
HBV & $\begin{array}{l}\text { AR signaling may affect the risk of } \\
\text { HBV-related HCC among men }\end{array}$ & 117 \\
HBV & $\begin{array}{l}\text { AR exon I CAG repeat length may } \\
\text { contribute to HCC predisposition }\end{array}$ & 118,119 \\
& among women \\
HBV & TNR of AR gene in male HCC & 120 \\
HBV & HBx enhances AR-responsive gene & 10,11, \\
& expression & $121-123$ \\
HBV & AR promotes HBV replication & $124-126$ \\
HBV & CCRK-AR regulates HBV- & 127 \\
HCV & associated HCC \\
NAFLD & HCV core augments AR-signaling & 12 \\
Alcohol & $\begin{array}{l}\text { association between AR, ER stress, } \\
\text { and hepatic lipid deposition }\end{array}$ & $86,128-130$ \\
& AR associated with severity of liver \\
\hline
\end{tabular}

Abbreviations: HCC, hepatocellular carcinoma; HBV, hepatitis B virus; TNR, trinucleotide repeats; $H B x$, hepatitis $B$ virus $X ; A R$, androgen-responsive; $H C V$, hepatitis $C$ virus; NAFLD, nonalcoholic fatty liver disease; ER, endoplasmic reticulum; CCRK, cell cycle-related kinase.

\section{ARs and androgen action}

Human AR is a member of the nuclear steroid receptor superfamily and AR gene is located on Xq11-12, indicating that males have a single copy of the gene..$^{32} \mathrm{AR}$ is a ligandactivated transcriptional factor with three domains: DNAbinding domain, C-terminal ligand-binding domain, and $\mathrm{N}$-terminal transactivation domain. ${ }^{33}$ Unliganded AR is inactivate and is bound to cytoplasmic chaperones such as heat shock protein 90 (Hsp90). ${ }^{34}$ Testosterone is produced in the testes and is converted to dihydrotestosterone. Ligands bind to $\mathrm{AR}$ and activate $\mathrm{AR}$, inducing conformational change. Then, the AR dimerizes and the AR-dimers translocate to the nucleus, where AR binds to consensus-binding sequences (androgen-responsive elements [AREs]) in the DNA to regulate target gene expression. ${ }^{34}$ Mitogen-activated protein kinase (MAPK)/extracellular signal-regulated protein kinase signaling increases the stability of AR. ${ }^{34}$ Interleukin-6 is sufficient to activate $\mathrm{AR}$ in vitro, and steroid receptor coactivator-1 has been shown in interleukin-6-dependent signaling. ${ }^{35}$ Steroid receptor coactivator-1 has been shown to interact with human AR and to modulate ligand-dependent AR transactivation, and it is regulated by phosphorylation by MAPK. ${ }^{35}$ Growth and survival pathways such as MAPK, $\mathrm{v}$-akt murine thymoma viral oncogene homolog 1 (AKT), and signal-transducer and activator of transcription (STAT) signaling are involved in the ligand-independent activation of AR of prostate cancer, pancreatic cancer, and HCC. ${ }^{12,35-40}$ It is also known that MAPK, AKT, and STAT could activate AR signaling, and they also are involved in human hepatocarcinogenesis. ${ }^{41-48}$ In several human cancers, AR seems to be activated in an androgen-dependent and/or androgen-independent manner (Figure 1).

\section{Target genes of AR in the liver $A R$ and its target genes}

Androgens and steroid hormones bind to the AR and, in turn, AR associates with genomic AREs (Table 2) ${ }^{49}$ In LNCap prostate cancer cells, more than 200 RNA expression levels are altered by androgen treatment. ${ }^{49-51}$ Androgen plays a critical role for the cytoskeleton and extracellular matrix in transducing signals for growth, differentiation, and secretion in normal and cancerous prostate cells $\mathrm{s}^{50,52}$ Upregulation of NF- $\mathrm{\kappa B}$ and several DNA repair or stress-response gene expressions may be a secondary response to oxidative stress rather than a direct response to AR signaling. ${ }^{50,53}$ Bolton et $\mathrm{al}^{49}$ reported that most androgen-responsive genes (ARGs) were associated with two or more AREs and that ARGs were sometimes themselves linked in gene clusters containing up to 13 AREs and 12 ARGs. Primary ARGs seem to produce effects on secondary target genes. ${ }^{50}$

\section{Androgen and the liver}

Human liver microsomes and cytochrome P450s (CYP) are major sites of metabolism of drugs and hormones. The liver could have an impact on the metabolism of androgen and the activation of AR or on the metabolism of antiandrogenic drugs such as flutamide. ${ }^{54,55}$ It was reported that downregulation of AR activity correlates with the severity of alcoholic liver injury. ${ }^{56}$ Hepatocyte nuclear factor-1 and CCAAT/enhancer-binding protein are responsible for liver specificity of the rat dehydroepiandrosterone sulfotransferase gene, which catalyzes sulfonation of androgenic steroids and certain aromatic procarcinogens. ${ }^{57}$

\section{$A R$ and transforming growth factor $\beta$ I (TGF- $\beta$ I) in the liver}

TGF- $\beta 1$ expression increases during progression of $\mathrm{HCC}, 58,59$ hepatic cirrhosis, ${ }^{60,61}$ hepatic damage, ${ }^{62,63}$ and hepatic regeneration. ${ }^{64,65}$ Yoon et al ${ }^{16}$ found that the promoter region of TGF- $\beta 1$ includes putative androgen response sequence and also in vivo and in vitro evidence of activation of TGF- $\beta 1$ expression by androgen and AR. They reported that androgen might regulate hepatocarcinogenesis by increasing 


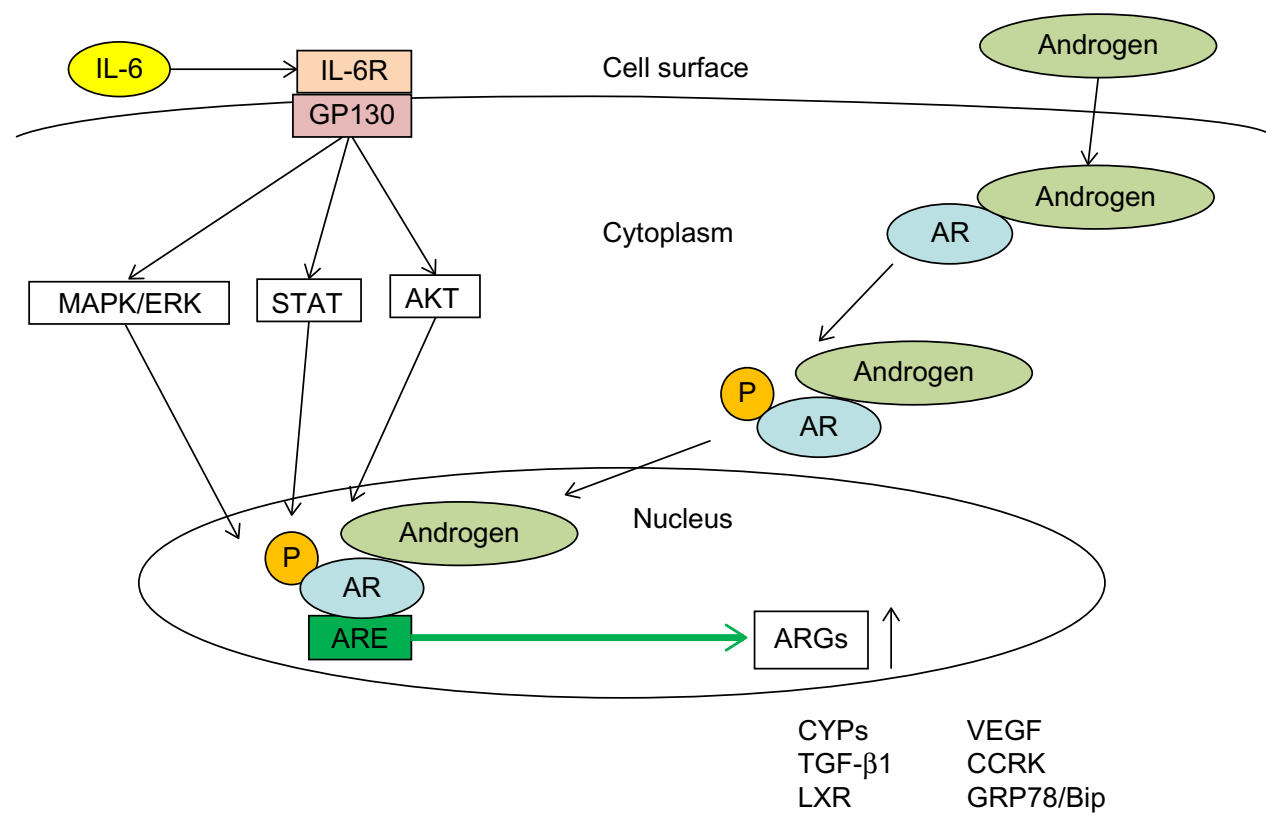

Figure I Ligand-dependent and ligand-independent androgen receptor (AR)-activation in hepatocytes.

Abbreviations: CYP, cytochrome P450; TGF- $\beta$ I, transforming growth factor $\beta$ I; LXR, liver-X-receptor; VEGF, vascular endothelial growth factor; CCRK, cell cycle-related kinase; GRP78/Bip, glucose-regulated protein 78 kDa; ARE, androgen-responsive element; ARGs, androgen-responsive genes; MAPK/ERK, mitogen-activated protein kinase/ extracellular signal-regulated protein kinase; STAT, signal-transducer and activator of transcription; AKT, v-akt murine thymoma viral oncogene homolog I; IL-6, interleukin-6; IL-6R, interleukin-6 receptor; GPI30, glycoprotein I30; P, phosphorylation.

transcription of TGF- $\beta 1$ through direct interactions with AR and ARE in the TGF- $\beta 1$ gene. ${ }^{66}$

\section{AR and cholesterol homeostasis in the liver}

AR signaling plays a role in the development and progression of several liver diseases, including HCC and nonalcoholic fatty liver disease. Androgen control of growth hormone secretion also induces male-specific genes in the liver. ${ }^{67} \mathrm{AR}$ activation results in obesity and altered lipid metabolism in orchidectomized mice, ${ }^{68}$ suggesting that the activation

Table 2 Representative ARGs in the liver

\begin{tabular}{lll}
\hline ARGs & Function & References \\
\hline CYPs & $\begin{array}{l}\text { Drug metabolism and alcohol } \\
\text { metabolism }\end{array}$ & $54-57,70$ \\
TGF- $\beta$ I & $\begin{array}{l}\text { HCC development, hepatic fibrosis, } \\
\text { hepatic damage, and hepatic } \\
\text { regeneration }\end{array}$ & 66 \\
& $\begin{array}{l}\text { Cholesterol homeostasis } \\
\text { LXR }\end{array}$ & 71 \\
VEGF & HCC development and angiogenesis & 12,49 \\
CCRK & HCC development & 75 \\
GRP78/Bip & ER stress and HCC development & 86,92
\end{tabular}

Abbreviations: ARG, androgen-responsive gene; CYP, cytochrome P450; ER, endoplasmic reticulum; HCC, hepatocellular carcinoma; TGF- $\beta$, transforming growth factor $\beta$ I; LXR, liver-X-receptor; VEGF, vascular endothelial growth factor; CCRK, cell cycle-related kinase; GRP78/Bip, glucose-regulated protein 78 kDa. of AR might be involved in HCC development in patients with nonalcoholic steatohepatitis, although there is also a contrary opinion. ${ }^{69}$ But these studies showed that hepatic AR may play a role in the development of insulin resistance and hepatic steatosis. ${ }^{68,69}$ CYP27A1 is a key enzyme in cholesterol homeostasis and vitamin $\mathrm{D}_{3}$ metabolism. $\mathrm{AR}$ could induce CYP27A1, which is a target for the JNK/c-Jun pathway. The JNK/c-Jun pathway is thought to be involved in AR-mediated upregulation of human CYP27A1. ${ }^{70}$ Krycer and Brown ${ }^{71}$ showed that liver-X-receptor activity is downregulated by AR. The cross-talk between AR and liver-Xreceptor is important for cholesterol homeostasis.

\section{AR and hepatocarcinogenesis}

Vascular endothelial growth factor (VEGF) is a target gene of $\mathrm{AR}^{49}$ and plays an important role in angiogenesis in the liver. ${ }^{12}$ Hepatitis $\mathrm{C}$ virus core protein enhances AR signaling, upregulates VEGF expression in hepatocytes, and facilitates angiogenesis. ${ }^{12}$ VEGF is one of the key molecules of treatment of HCC. ${ }^{72,73}$ Of interest, female sex was associated with better response to sorafenib in patients with unresectable $\mathrm{HCC}$ in Japan. ${ }^{74}$ Feng et al reported that cell cycle-related kinase is a direct AR transcriptional target and that cell cycle-related kinase promotes hepatocarcinogenesis through the upregulation of $\beta$-catenin/TCF signaling. ${ }^{75}$ 


\section{$A R$ and aryl hydrocarbon (or dioxin) receptor}

Both aryl hydrocarbon (or dioxin) receptor and aryl hydrocarbon (or dioxin) receptor nuclear translocator are known to interact with AR. ${ }^{39,76,77}$ AR might also be involved in hepatocarcinogenesis through aryl hydrocarbon (or dioxin) receptor pathways. ${ }^{39} \mathrm{Li}$ et $\mathrm{al}^{78}$ reported that the vertebrae forkhead box A factors and their targets estrogen receptor $\alpha$ and AR play an important role in the sex difference of HCC. Nuclear receptors including AR and estrogen receptor and their related signaling pathways play a role in human hepatocarcinogenesis. ${ }^{40}$

\section{$A R$ and cell migration}

Recent studies revealed that AR is involved in cell migration and metastasis. ${ }^{79}$ At present, it is not clear whether AR could promote cell migration ${ }^{81-83}$ or not. ${ }^{80,84,85}$ Although further studies will be needed regarding this point, $A R$ is one of the important target molecules for treatment targeting metastasis or advanced HCC.

\section{AR and endoplasmic reticulum stress}

Dihydrotestosterone could induce RNA-dependent protein kinase/eukaryotic initiation factor-2 $\alpha$ activation in human hepatocytes. ${ }^{86}$ Dai et al ${ }^{86}$ reported that RNA-dependent protein kinase/eukaryotic initiation factor- $2 \alpha$ activation is involved in dihydrotestosterone-induced cell cycle arrest and that the eukaryotic initiation factor-2 $\alpha /$ GADD153 pathway, a branch of ER stress response, is enhanced. It is well known that the ER stress pathway is involved in human hepatocarcinogenesis ${ }^{87}$ Glucose-regulated protein $78 \mathrm{kDa}$ (GRP78/Bip) is one of the androgen response genes in human prostate cells as well as in human hepatocytes..$^{39,88-92}$ We reported that stronger positive correlations between the expressions of AR mRNA and GRP78 mRNA in stage I/II HCC samples, compared with stage III/IV HCC samples, indicated that AR-controlling GRP78 activation plays a role in hepatocarcinogenesis in especially earlier-stage HCC patients. ${ }^{92}$ We also observed that AR overexpression increased ER stress-responsive gene expression in human hepatocytes and that AR-knockdown led to the downregulation of expression of ER stress molecules. ${ }^{92}$ We also confirmed that the double-knockdown of AR and GRP78 enhanced sorafenib-induced apoptosis in human hepatoma cell lines ${ }^{92}$ The cross-talk between AR and ER stress response might be a potential target in the treatment of HCC.

\section{$A R$ and Toll-like receptor signaling pathways}

Tissue expression of AR is associated with differential immune responsiveness. ${ }^{93}$ Toll-like receptors (TLRs) are a family of transmembrane receptors and play central roles in innate immunity. TLR4 recognizes lipopolysaccharide, a cell wall component of gram-negative bacteria that activate innate immunity. ${ }^{94}$ Lipopolysaccharide induced apoptosis in hepatocytes and reduced the hepatic expressions of ER stress-related proteins. ER stress response is important for hepatic cell damage from an innate immune response. ${ }^{94}$

Testosterone downregulated the expression of several TLR genes, possibly resulting in the inhibition of the immune response. ${ }^{95}$ MyD88, downstream of TLR4, may play a role in limiting prostate tumorigenesis by altering tumor-infiltrating immune populations. ${ }^{96}$ We observed an increase of lipopolysaccharide-induced apoptosis $(67 \%)$ in HepG2 stably expressing shAR as compared to that (47\%) in HepG2 control cells..$^{92}$ AR and ER stress response may be involved in innate immune response of hepatocytes.

\section{$A R$ and other signaling pathways}

Several reports indicated that insulin-like growth factor (IGF), fibroblast growth factor (FGF), and VEGF, as well as mammalian target of the rapamycin (mTOR) signaling pathways are involved in human hepatocarcinogenesis. ${ }^{48,97-99}$ Cell surface receptors for IGF, FGF, and VEGF activate downstream signal transduction through the receptor-tyrosine kinases. These receptors are also important molecular targets for drugs against HCC such as sorafenib, brivanib, and everolimus. ${ }^{48,97-99}$

IGF-1 and its binding proteins are also known as ARtargeting genes in prostate cancer cells. ${ }^{100,101}$ Tsuei et al ${ }^{102}$ showed that downregulation of IGF-1 and its binding protein-3 were observed in the RNA-binding motif gene on the $\mathrm{Y}$ chromosome-knockdown HepG2 cells, suggesting the enhancing effect of RNA-binding motif gene on the $\mathrm{Y}$ chromosome on AR transactivation activity in human HCC.

AR could control FGF and FGF-binding protein production and affect FGF signaling pathway in prostate cancer cells. ${ }^{103}$ AR may have an impact on FGF signaling pathway as well as VEGF signaling pathways in human hepatocarcinogenesis. ${ }^{12} \mathrm{PI} 3 \mathrm{~K} / \mathrm{phosphatase}$ and tensin homologs deleted on chromosome 10 (PTEN)/Akt/mTOR pathway are involved in many cellular processes of human HCC. ${ }^{48}$ Everolimus and sirolimusis could inhibit HCC 
Table 3 Clinical trials targeting androgen in hepatocellular carcinoma

\begin{tabular}{|c|c|c|c|c|c|c|}
\hline Drug (dosage) & $\begin{array}{l}\text { Randomized } \\
\text { study }\end{array}$ & $\begin{array}{l}\text { Number } \\
\text { of patients }\end{array}$ & $\begin{array}{l}\text { Eligibility } \\
\text { Child-Pugh class }\end{array}$ & Stage of $\mathrm{HCC}$ & $\begin{array}{l}\text { Efficacy: mean } \\
\text { survival or response }\end{array}$ & Ref \\
\hline $\begin{array}{l}\text { Leuprorelin, flutamide, } \\
\text { and tamoxifen }\end{array}$ & Yes & 192 & $\begin{array}{l}\text { Child-Pugh Class A/B/C: } \\
\text { II2/50/2; cirrhosis, } 90 \% \text {; } \\
\text { ascites, } 26 \% \text {; HBV, 3\%; HCV, 19\% }\end{array}$ & $\begin{array}{l}\text { Okuda's } \\
\text { classification stage } \\
\text { I/II/III: } 8 \mathrm{I} / \mathrm{I} 07 / 4\end{array}$ & $135.5 \mathrm{~d}(P=0.2 \mathrm{I})$ & 108 \\
\hline $\begin{array}{l}\text { Tamoxifen (administered } \\
\text { until death) }\end{array}$ & Yes & 184 & $\begin{array}{l}\text { Child-Pugh Class A/B/C: I05/59/5; } \\
\text { cirrhosis, } 93 \% \text {; ascites, 31\%; } \\
\text { HBV, I0\%; HCV, I3\% }\end{array}$ & $\begin{array}{l}\text { Okuda's } \\
\text { classification stage } \\
\text { I/II/III: } 93 / 83 / 8\end{array}$ & $176 d$ & 108 \\
\hline Flutamide for 8 weeks & Phase II & 32 & $\begin{array}{l}\text { Measurable advanced HCC } \\
\text { patients; hepatitis-related, } 88 \%\end{array}$ & $\begin{array}{l}\text { AJCC stage III/ } \\
\text { IV: } 5 / 27\end{array}$ & $\begin{array}{l}\text { I0 wks; } 9 \text { of } 22(41 \%), \\
\text { stable diseases; I } 3(59 \%), \\
\text { progress diseases }\end{array}$ & 109 \\
\hline $\begin{array}{l}\text { Antiandrogen (Anandron) } \\
\text { plus placebo }\end{array}$ & Yes & 58 & $\begin{array}{l}\text { Unresectable HCC; cirrhosis, } \\
76 \% \text {; HBV, } 25 \%\end{array}$ & $\mathrm{~N} / \mathrm{A}$ & $\begin{array}{l}3.6 \text { mo }(\mathrm{NS}) ; \text { I, complete } \\
\text { response }\end{array}$ & 110 \\
\hline $\begin{array}{l}\text { LHRH agonist plus } \\
\text { placebo }\end{array}$ & Yes & 61 & $\begin{array}{l}\text { Unresectable HCC; cirrhosis, } \\
85 \% \text {; HBV, } 21 \%\end{array}$ & $\mathrm{~N} / \mathrm{A}$ & $\begin{array}{l}2.7 \text { mo }(\mathrm{NS}) ; \text { I, partial } \\
\text { response }\end{array}$ & 110 \\
\hline $\begin{array}{l}\text { Antiandrogen plus LHRH } \\
\text { agonist }\end{array}$ & Yes & 60 & $\begin{array}{l}\text { Unresectable HCC; cirrhosis, } \\
82 \% \text {; HBV, I4\% }\end{array}$ & $\mathrm{N} / \mathrm{A}$ & $\begin{array}{l}3.9 \text { mo (NS); I, partial } \\
\text { response }\end{array}$ & 110 \\
\hline Placebo plus placebo & Yes & 59 & $\begin{array}{l}\text { Unresectable HCC; cirrhosis, } \\
83 \% ; \mathrm{HBV}, 35 \%\end{array}$ & $\mathrm{~N} / \mathrm{A}$ & $5.8 \mathrm{mo}$ & 110 \\
\hline Cyproterone acetate & No & 25 & Cirrhotics with unresectable HCC & N/A & $\begin{array}{l}14 \text { wks; } \\
5 \text {, excess in } 29 \text { wks; } \\
5 \text {, response }\end{array}$ & III \\
\hline Ketoconazole & No & 8 & Unresectable HCC & N/A & $6,<8$ weeks & 112 \\
\hline $\begin{array}{l}\text { D-Tryptophan-6- } \\
\text { luteinizing hormone-- } \\
\text { releasing hormone }\end{array}$ & No & 17 & Cirrhotics with $\mathrm{HCC}$ & $\mathrm{N} / \mathrm{A}$ & No response & 113 \\
\hline $\begin{array}{l}\text { LHRH-analog triptorelin } \\
\text { and tamoxifene }\end{array}$ & Yes & 33 & $\begin{array}{l}\text { Child-Pugh: } 7.7 \pm 2.0 \text { (untreated } \\
\mathrm{HCC} \text { ); cirrhosis, } 27 ; \mathrm{HBsAg}(+) \text {, } \\
69.7 \% \text {; anti-HDV (+), } 15.2 \% \text {; } \\
\text { anti-HCV }(+), 12.1 \%\end{array}$ & $\begin{array}{l}\text { Okuda stage } I / I I I \\
(\%): 27.3 / 18.2\end{array}$ & $\begin{array}{l}282 \mathrm{~d}(P=0.020 \mathrm{vs} \\
\text { placebo })\end{array}$ & 114 \\
\hline Triptorelin plus flutamide & Yes & 23 & $\begin{array}{l}\text { Child-Pugh: } 8.3 \pm 1.6 \text { (untreated } \\
\text { HCC); cirrhosis, } 18 ; \mathrm{HBsAg}(+) \text {, } \\
56.5 \% \text {; anti-HDV }(+), 8.7 \% \text {; } \\
\text { anti-HCV }(+), 8.7 \%\end{array}$ & $\begin{array}{l}\text { Okuda stage } 1 / I I I \\
(\%): 21.7 / 13.0\end{array}$ & II 2 d (NS vs placebo) & 114 \\
\hline Placebo & Yes & 29 & $\begin{array}{l}\text { Child-Pugh: } 8.9 \pm 2 . \text { ( (untreated } \\
\text { HCC); cirrhosis, } 25 ; \mathrm{HBsAg}(+) \text {, } \\
58.6 \% \text {; anti-HDV (+), } 10.7 \% \text {; } \\
\text { anti-HCV (+), } 20.0 \%\end{array}$ & $\begin{array}{l}\text { Okuda stage } 1 / I I I \\
\text { (\%): } 24.1 / 17.2\end{array}$ & $127 d$ & 114 \\
\hline
\end{tabular}

Abbreviations: AJCC, American Joint Committee on Cancer; HBV, hepatitis B virus; HCV, hepatitis C virus; HDV, hepatitis delta virus; HBsAg, hepatitis B virus surface antigen; LHRH, luteinizing hormone-releasing hormone; HCC, hepatocellular carcinoma; Ref, references; NS, not significant; N/A, not applicable; d, days; wks, weeks; mo, months; vs, versus.

growth through this signaling pathway. ${ }^{48}$ Previous study in prostate cancer cell lines ${ }^{104}$ showed AR-mTOR cross-talk is regulated by testosterone availability. Further study will be needed at a significance of AR-mTOR cross-talk in human hepatocarcinogenesis.

\section{HBV and AR}

Chen and Yehs' group has extensively studied the association between $\mathrm{HBV}$ infection and AR, or the association between HBx protein and $A R$, and reported that $A R$ is involved in human hepatocarcinogenesis. ${ }^{38,39,105-107}$ Table 1 shows several mechanisms of the effects of AR in HBV-associated HCC. Many studies with human liver tissues ${ }^{13-31}$ also support this concept. These data support the idea that AR could be one of the important molecular targets for the treatment of HCC with or without HBV infection.

\section{Conclusion}

AR could play critical roles in human HCC and be one of the important target molecules for the treatment of HCC. The previous controlled study shows the lack of efficacy of androgen treatment in unresectable HCC (Table 3). ${ }^{108-115}$ However, the present review clearly suggests that AR but not androgen could be an important target of hepatocarcinogenesis and HCC development, and more specific inhibitors of AR would shed light on the treatment of HCC. 
Further studies concerning AR and ARGs in the liver should be carried out.

\section{Acknowledgments}

This work was supported by a KAKEN Grant-in-Aid for Scientific Research from the Ministry of Education, Culture, Sports, Science, and Technology of Japan (24590955).

\section{Disclosure}

The authors report no conflicts of interest in this work.

\section{References}

1. Yamashita YI, Yoshida Y, Kurihara T, et al. Surgical results for recurrent hepatocellular carcinoma after curative hepatectomy: repeat hepatectomy vs salvage living donor liver transplantation. Liver Transpl. 2015.

2. Llovet JM, Ricci S, Mazzaferro V, et al; SHARP Investigators Study Group. Sorafenib in advanced hepatocellular carcinoma. NEngl J Med. 2008:359(4):378-390.

3. Furuse J, Ishii H, Nakachi K, Suzuki E, Shimizu S, Nakajima K. Phase I study of sorafenib in Japanese patients with hepatocellular carcinoma. Cancer Sci. 2008;99(1):159-165.

4. Shiina S, Tateishi R, Arano T, et al. Radiofrequency ablation for hepatocellular carcinoma: 10-year outcome and prognostic factors. Am J Gastroenterol. 2012;107(4):569-577.

5. El-Serag HB. Hepatocellular carcinoma. N Engl J Med. 2011; 365(12): 1118-1127.

6. Shiratori Y, Shiina S, Imamura M, et al. Characteristic difference of hepatocellular carcinoma between hepatitis B- and C-viral infection in Japan. Hepatology. 1995;22(4 pt 1):1027-1033.

7. Tateishi R, Okanoue T, Fujiwara N, et al. Clinical characteristics, treatment, and prognosis of non-B, non-C hepatocellular carcinoma: a large retrospective multicenter cohort study. $J$ Gastroenterol. 2015;50(3):350-360.

8. Naugler WE, Sakurai T, Kim S, et al. Gender disparity in liver cancer due to sex differences in MyD88-dependent IL-6 production. Science. 2007;317(5834):121-124.

9. Zhao Y, Li Z. Interplay of estrogen receptors and FOXA factors in the liver cancer. Mol Cell Endocrinol. 2015.

10. Chiu CM, Yeh SH, Chen PJ, et al. Hepatitis B virus X protein enhances androgen receptor-responsive gene expression depending on androgen level. Proc Natl Acad Sci U S A. 2007;104(8):2571-2578.

11. Zheng Y, Chen WL, Ma WL, Chang C, Ou JH. Enhancement of gene transactivation activity of androgen receptor by hepatitis B virus $\mathrm{X}$ protein. Virology. 2007;363(2):454-461.

12. Kanda T, Steele R, Ray R, Ray RB. Hepatitis C virus core protein augments androgen receptor-mediated signaling. J Virol. 2008;82(22): 11066-11072.

13. Iqbal MJ, Wilkinson ML, Johnson PJ, Williams R. Sex steroid receptor proteins in foetal, adult and malignant human liver tissue. Br J Cancer. 1983;48(6):791-796.

14. Wong LY, Chan SH, Oon CJ, Rauff A. Immunocytochemical localization of testosterone in human hepatocellular carcinoma. Histochem J. 1984;16(6):687-692.

15. Nagasue N, Yukaya H, Chang YC, Ogawa Y, Kohno H, Ito A. Active uptake of testosterone by androgen receptors of hepatocellular carcinoma in humans. Cancer. 1986;57(11):2162-2167.

16. Nagasue N, Ito A, Yukaya $\mathrm{H}$, Ogawa Y. Androgen receptors in hepatocellular carcinoma and surrounding parenchyma. Gastroenterology. 1985; 89(3):643-647.

17. Wilkinson ML, Iqbal MJ, Williams R. Characterisation of high affinity binding sites of androgens in primary hepatocellular carcinoma. Clin Chim Acta. 1985;152(1-2):105-113.
18. Ohnishi S, Murakami T, Moriyama T, Mitamura K, Imawari M. Androgen and estrogen receptors in hepatocellular carcinoma and in the surrounding noncancerous liver tissue. Hepatology. 1986;6(3):440-443.

19. Bannister P, Meystre CM, Losowsky MS. Androgen receptor concentrations in needle biopsy specimens of human liver. Liver. 1988;8(1):28-31.

20. Nagasue N, Kohno H, Chang YC, et al. Androgen and estrogen receptors in hepatocellular carcinoma and the surrounding liver in women. Cancer. 1989;63(1):112-116.

21. Nagasue N, Chang YC, Hayashi T, et al. Androgen receptor in hepatocellular carcinoma as a prognostic factor after hepatic resection. Ann Surg. 1989;209(4):424-427.

22. Nagasue N, Kohno H, Chang Y, Hayashi T, Nakamura T. Specificity of androgen receptors of hepatocellular carcinoma and liver in humans. Hepatogastroenterology. 1990;37(5):474-479.

23. Nagasue N, Kohno H, Yamanoi A, Kimoto T, Chang YC, Nakamura T. Progesterone receptor in hepatocellular carcinoma. Correlation with androgen and estrogen receptors. Cancer. 1991;67(10):2501-2505.

24. Eagon PK, Francavilla A, DiLeo A, et al. Quantitation of estrogen and androgen receptors in hepatocellular carcinoma and adjacent normal human liver. Dig Dis Sci. 1991;36(9):1303-1308.

25. Nagasue N, Yamanoi A, Kohno H, et al. Androgen receptor in cirrhotic liver, adenomatous hyperplastic nodule and hepatocellular carcinoma in the human. Hepatogastroenterology. 1992;39(5):455-460.

26. Boix L, Bruix J, Castells A, et al. Sex hormone receptors in hepatocellular carcinoma. Is there a rationale for hormonal treatment? $J$ Hepatol. 1993;17(2):187-191.

27. Negro F, Papotti M, Pacchioni D, Galimi F, Bonino F, Bussolati G. Detection of human androgen receptor mRNA in hepatocellular carcinoma by in situ hybridisation. Liver. 1994;14(4):213-219.

28. Boix L, Castells A, Bruix J, et al. Androgen receptors in hepatocellular carcinoma and surrounding liver: relationship with tumor size and recurrence rate after surgical resection. $J$ Hepatol. 1995;22(6): 616-622.

29. Tavian D, De Petro G, Pitozzi A, Portolani N, Giulini SM, Barlati S. Androgen receptor mRNA under-expression in poorly differentiated human hepatocellular carcinoma. Histol Histopathol. 2002;17(4): $1113-1119$

30. Vizoso FJ, Rodriguez M, Altadill A, et al. Liver expression of steroid hormones and apolipoprotein D receptors in hepatocellular carcinoma. World J Gastroenterol. 2007;13(23):3221-3227.

31. Zhang Y, Shen Y, Cao B, Yan A, Ji H. Elevated expression levels of androgen receptors and matrix metalloproteinase- 2 and -9 in 30 cases of hepatocellular carcinoma compared with adjacent tissues as predictors of cancer invasion and staging. Exp Ther Med. 2015;9(3): 905-908.

32. Hughes IA, Davies JD, Bunch TI, Pasterski V, Mastroyannopoulou K, MacDougall J. Androgen insensitivity syndrome. Lancet. 2012;380(9851):1419-1428.

33. Gelmann EP. Molecular biology of the androgen receptor. J Clin Oncol. 2002;20(13):3001-3015.

34. Shafi AA, Yen AE, Weigel NL. Androgen receptors in hormonedependent and castration-resistant prostate cancer. Pharmacol Ther. 2013;140(3):223-238.

35. Ueda T, Mawji NR, Bruchovsky N, Sadar MD. Ligand-independent activation of the androgen receptor by interleukin- 6 and the role of steroid receptor coactivator-1 in prostate cancer cells. $J$ Biol Chem. 2002;277(41):38087-38094.

36. Culig Z, Hobisch A, Cronauer MV, et al. Androgen receptor activation in prostatic tumor cell lines by insulin-like growth factor-I, keratinocyte growth factor, and epidermal growth factor. Cancer Res. 1994;54(20):5474-5478.

37. Okitsu $\mathrm{K}$, Kanda $\mathrm{T}$, Imazeki $\mathrm{F}$, et al. Involvement of interleukin-6 and androgen receptor signaling in pancreatic cancer. Genes Cancer. 2010;1(8):859-867.

38. Kanda T, Yokosuka O, Omata M. Androgen receptor and hepatocellular carcinoma. J Gastroint Dig Syst. 2013:S12. 
39. Kanda T, Jiang X, Yokosuka O. Androgen receptor signaling in hepatocellular carcinoma and pancreatic cancers. World J Gastroenterol. 2014;20(28):9229-9236.

40. Wu S, Kanda T, Imazeki F, Nakamoto S, Shirasawa H, Yokosuka O Nuclear receptor mRNA expression by HBV in human hepatoblastoma cell lines. Cancer Lett. 2011;312(1):33-42.

41. Tanaka S, Mohr L, Schmidt EV, Sugimachi K, Wands JR. Biological effects of human insulin receptor substrate-1 overexpression in hepatocytes. Hepatology. 1997;26(3):598-604.

42. Ito Y, Sasaki Y, Horimoto M, et al. Activation of mitogen-activated protein kinases/extracellular signal-regulated kinases in human hepatocellular carcinoma. Hepatology. 1998;27(4):951-958.

43. Suzuki A, Hayashida M, Kawano H, Sugimoto K, Nakano T, Shiraki K. Hepatocyte growth factor promotes cell survival from fas-mediated cell death in hepatocellular carcinoma cells via Akt activation and Fas-death-inducing signaling complex suppression. Hepatology. 2000;32(4 pt 1):796-802.

44. Fujimaki S, Matsuda Y, Wakai T, et al. Blockade of ataxia telangiectasia mutated sensitizes hepatoma cell lines to sorafenib by interfering with Akt signaling. Cancer Lett. 2012;319(1):98-108.

45. Sato M, Matsuda Y, Wakai T, et al. P21-activated kinase-2 is a critical mediator of transforming growth factor- $\beta$-induced hepatoma cell migration. J Gastroenterol Hepatol. 2013;28(6):1047-1055.

46. Matsuda Y, Wakai T, Kubota M, et al. Valproic acid overcomes transforming growth factor- $\beta$-mediated sorafenib resistance in hepatocellular carcinoma. Int J Clin Exp Pathol. 2014;7(4):1299-1313.

47. Yoshikawa H, Matsubara K, Qian GS, et al. SOCS-1, a negative regulator of the JAK/STAT pathway, is silenced by methylation in human hepatocellular carcinoma and shows growth-suppression activity. Nat Genet 2001;28(1):29-35.

48. Kanda T, Imazeki F, Kanai F, Tada M, Yokosuka O, Omata M. Signaling pathways involved in molecular carcinogenesis of HCC. In: Qiao L, Yan X, Li Y, George Y, editors. Molecular Aspect of Hepatocellular Carcinoma. Sharjah: Bentham Science Publishers; 2012:39-55

49. Bolton EC, So AY, Chaivorapol C, Haqq CM, Li H, Yamamoto KR. Cell- and gene-specific regulation of primary target genes by the androgen receptor. Genes Dev. 2007;21(16):2005-2017.

50. DePrimo SE, Diehn M, Nelson JB, et al. Transcriptional programs activated by exposure of human prostate cancer cells to androgen. Genome Biol. 2002;3(7):RESEARCH0032.

51. Nelson PS, Clegg N, Arnold H, et al. The program of androgenresponsive genes in neoplastic prostate epithelium. Proc Natl Acad Sci US A. 2002;99(18):11890-11895

52. Getzenberg RH, Pienta KJ, Ward WS, Coffey DS. Nuclear structure and the three-dimensional organization of DNA. $J$ Cell Biochem. 1991;47(4):289-299.

53. Ripple MO, Henry WF, Schwarze SR, Wilding G, Weindruch R. Effect of antioxidants on androgen-induced AP-1 and NF-kappaB DNA-binding activity in prostate carcinoma cells. J Natl Cancer Inst. 1999;91(14):1227-1232.

54. Shet MS, McPhaul M, Fisher CW, Stallings NR, Estabrook RW. Metabolism of the antiandrogenic drug (Flutamide) by human CYP1A2. Drug Metab Dispos. 1997;25(11):1298-1303.

55. Gehlhaus M, Schmitt N, Volk B, Meyer RP. Antiepileptic drugs affect neuronal androgen signaling via a cytochrome P450-dependent pathway. J Pharmacol Exp Ther. 2007;322(2):550-559.

56. Eagon PK, Elm MS, Tadic SD, Nanji AA. Downregulation of nuclear sex steroid receptor activity correlates with severity of alcoholic liver injury. Am J Physiol Gastrointest Liver Physiol. 2001;281(2):G342-G439.

57. Song CS, Jung MH, Kim SC, Hassan T, Roy AK, Chatterjee B. Tissue-specific and androgen-repressible regulation of the rat dehydroepiandrosterone sulfotransferase gene promoter. J Biol Chem. 1998;273(34):21856-21866.

58. Ito N, Kawata S, Tamura S, et al. Elevated levels of transforming growth factor beta messenger RNA and its polypeptide in human hepatocellular carcinoma. Cancer Res. 1991;51(15):4080-4083.
59. Nagahara H, Ezhevsky SA, Vocero-Akbani AM, Kaldis P, Solomon MJ, Dowdy SF. Transforming growth factor beta targeted inactivation of cyclin E:cyclin-dependent kinase 2 ( Cdk2) complexes by inhibition of Cdk2 activating kinase activity. Proc Natl Acad Sci U S A. 1999; 96(26):14961-14966.

60. Roberts AB, Sporn MB, Assoian RK, et al. Transforming growth factor type beta: rapid induction of fibrosis and angiogenesis in vivo and stimulation of collagen formation in vitro. Proc Natl Acad Sci USA. 1986;83(12):4167-4171.

61. Tsukamoto H, Matsuoka M, French SW. Experimental models of hepatic fibrosis: a review. Semin Liver Dis. 1990;10(1):56-65.

62. Yager JD, Zurlo J, Ni N. Sex hormones and tumor promotion in liver. Proc Soc Exp Biol Med. 1991;198(2):667-674.

63. Lin JK, Chou CK. In vitro apoptosis in the human hepatoma cell line induced by transforming growth factor beta 1. Cancer Res. 1992;52(2):385-388.

64. Fausto N, Mead JE, Braun L, et al. Proto-oncogene expression and growth factors during liver regeneration. Symp Fundam Cancer Res. 1986;39:69-86.

65. Braun L, Mead JE, Panzica M, Mikumo R, Bell GI, Fausto N. Transforming growth factor beta mRNA increases during liver regeneration: a possible paracrine mechanism of growth regulation. Proc Natl Acad Sci USA. 1988;85(5):1539-1543.

66. Yoon G, Kim JY, Choi YK, Won YS, Lim IK. Direct activation of TGF-beta1 transcription by androgen and androgen receptor complex in Huh7 human hepatoma cells and its tumor in nude mice. $J$ Cell Biochem. 2006;97(2):393-411.

67. Robins DM. Androgen receptor and molecular mechanisms of malespecific gene expression. Novartis Found Symp. 2005;268:42-52.

68. Movérare-Skrtic S, Venken K, Andersson N, et al. Dihydrotestosterone treatment results in obesity and altered lipid metabolism in orchidectomized mice. Obesity (Silver Spring). 2006;14(4):662-672.

69. Lin HY, Yu IC, Wang RS, et al. Increased hepatic steatosis and insulin resistance in mice lacking hepatic androgen receptor. Hepatology. 2008;47(6):1924-1935.

70. Norlin M, Pettersson H, Tang W, Wikvall K. Androgen receptor-mediated regulation of the anti-atherogenic enzyme CYP27A1 involves the JNK/c-jun pathway. Arch Biochem Biophys. 2011;506(2):236-241.

71. Krycer JR, Brown AJ. Cross-talk between the androgen receptor and the liver X receptor: implications for cholesterol homeostasis. J Biol Chem. 2011;286(23):20637-20647.

72. Schöffski P, Dumez H, Clement P, et al. Emerging role of tyrosine kinase inhibitors in the treatment of advanced renal cell cancer: a review. Ann Oncol. 2006;17(8):1185-1196.

73. Kudo M, Ueshima K. Positioning of a molecular-targeted agent, sorafenib, in the treatment algorithm for hepatocellular carcinoma and implication of many complete remission cases in Japan. Oncology. 2010;78(Suppl 1):154-166.

74. Takeda H, Nishikawa H, Osaki Y, et al; Japanese Red Cross Liver Study Group. Clinical features associated with radiological response to sorafenib in unresectable hepatocellular carcinoma: a large multicenter study in Japan. Liver Int. 2015;35(5):1581-1589.

75. Feng H, Cheng AS, Tsang DP, et al. Cell cycle-related kinase is a direct androgen receptor-regulated gene that drives $\beta$-catenin/T cell factor-dependent hepatocarcinogenesis. J Clin Invest. 2011;121(8):3159-3175.

76. Krüger T, Long M, Bonefeld-Jørgensen EC. Plastic components affect the activation of the aryl hydrocarbon and the androgen receptor. Toxicology. 2008;246(2-3):112-123.

77. Wu Y, Baumgarten SC, Zhou P, Stocco C. Testosterone-dependent interaction between androgen receptor and aryl hydrocarbon receptor induces liver receptor homolog 1 expression in rat granulosa cells. $\mathrm{Mol}$ Cell Biol. 2013;33(15):2817-2828.

78. Li Z, Tuteja G, Schug J, Kaestner KH. Foxa1 and Foxa2 are essential for sexual dimorphism in liver cancer. Cell. 2012;148(1-2):72-83.

79. Shen F, Yan C, Liu M, Feng Y, Chen Y. RACK1 promotes prostate cancer cell proliferation, invasion and metastasis. Mol Med Rep. 2013; 8(4):999-1004. 
80. Ma WL, Hsu CL, Yeh CC, et al. Hepatic androgen receptor suppresses hepatocellular carcinoma metastasis through modulation of cell migration and anoikis. Hepatology. 2012;56(1):176-185.

81. Ao J, Meng J, Zhu L, et al. Activation of androgen receptor induces ID1 and promotes hepatocellular carcinoma cell migration and invasion. Mol Oncol. 2012;6(5):507-515.

82. Huang CK, Lee SO, Lai KP, et al. Targeting androgen receptor in bone marrow mesenchymal stem cells leads to better transplantation therapy efficacy in liver cirrhosis. Hepatology. 2013;57(4):1550-1563.

83. Nie H, Cao Q, Zhu L, Gong Y, Gu J, He Z. Acetylcholine acts on androgen receptor to promote the migration and invasion but inhibit the apoptosis of human hepatocarcinoma. PLoS One. 2013;8(4):e61678.

84. Ma WL, Lai HC, Yeh S, Cai X, Chang C. Androgen receptor roles in hepatocellular carcinoma, fatty liver, cirrhosis and hepatitis. Endocr Relat Cancer. 2014;21(3):R165-R182.

85. Ma WL, Jeng LB, Lai HC, Liao PY, Chang C. Androgen receptor enhances cell adhesion and decreases cell migration via modulating $\beta 1$-integrin-AKT signaling in hepatocellular carcinoma cells. Cancer Lett. 2014;351(1):64-71.

86. Dai R, Yan D, Li J, et al. Activation of PKR/eIF2 $\alpha$ signaling cascade is associated with dihydrotestosterone-induced cell cycle arrest and apoptosis in human liver cells. J Cell Biochem. 2012;113(5):1800-1808.

87. Shuda M, Kondoh N, Imazeki N, et al. Activation of the ATF6, XBP1 and grp78 genes in human hepatocellular carcinoma: a possible involvement of the ER stress pathway in hepatocarcinogenesis. $J$ Hepatol. 2003;38(5):605-614.

88. Tan SS, Ahmad I, Bennett HL, et al. GRP78 up-regulation is associated with androgen receptor status, Hsp70-Hsp90 client proteins and castrate-resistant prostate cancer. J Pathol. 2011;223(1):81-87.

89. Bennett HL, Fleming JT, O'Prey J, Ryan KM, Leung HY. Androgens modulate autophagy and cell death via regulation of the endoplasmic reticulum chaperone glucose-regulated protein $78 / \mathrm{BiP}$ in prostate cancer cells. Cell Death Dis. 2010;1:e72.

90. Kim SS, Cho HJ, Kang JY, Kang HK, Yoo TK. Inhibition of androgen receptor expression with small interfering RNA enhances cancer cell apoptosis by suppressing survival factors in androgen insensitive, late stage LNCaP cells. Scientific World Journal. 2013;2013:519397.

91. Yang YC, Fu HC, Hsiao BL, et al. Androgen receptor inclusions acquire GRP78/BiP to ameliorate androgen-induced protein misfolding stress in embryonic stem cells. Cell Death Dis. 2013;4:e607.

92. Jiang X, Kanda T, Nakamoto S, Miyamura T, Wu S, Yokosuka O. Involvement of androgen receptor and glucose-regulated protein $78 \mathrm{kDa}$ in human hepatocarcinogenesis. Exp Cell Res. 2014;323(2):326-336.

93. Butts CL, Jones YL, Lim JK, Salter CE, Belyavskaya E, Sternberg EM. Tissue expression of steroid hormone receptors is associated with differential immune responsiveness. Brain Behav Immun. 2011;25(5): $1000-1007$

94. Jiang X, Kanda T, Tanaka T, et al. Lipopolysaccharide blocks induction of unfolded protein response in human hepatoma cell lines. Immunol Lett. 2013;152(1):8-15.

95. Sánchez-HernándezM,Chaves-PozoE, Cabas I, MuleroV,García-AyalaA, García-Alcázar A. Testosterone implants modify the steroid hormone balance and the gonadal physiology of gilthead seabream (Sparus aurata L) males. J Steroid Biochem Mol Biol. 2013;138:183-194.

96. Peek EM, Song W, Zhang H, Huang J, Chin AI. Loss of MyD88 leads to more aggressive TRAMP prostate cancer and influences tumor infiltrating lymphocytes. Prostate. 2015;75(5):463-473.

97. Huynh H, Ngo VC, Koong HN, et al. Sorafenib and rapamycin induce growth suppression in mouse models of hepatocellular carcinoma. J Cell Mol Med. 2009;13(8B):2673-2683.

98. Huynh H, Ngo VC, Fargnoli J, et al. Brivanib alaninate, a dual inhibitor of vascular endothelial growth factor receptor and fibroblast growth factor receptor tyrosine kinases, induces growth inhibition in mouse models of human hepatocellular carcinoma. Clin Cancer Res. 2008;14(19): 6146-6153.

99. Huynh H, Chow KH, Soo KC, et al. RAD001 (everolimus) inhibits tumour growth in xenograft models of human hepatocellular carcinoma. J Cell Mol Med. 2009;13(7):1371-1380.
100. Peng L, Malloy PJ, Wang J, Feldman D. Growth inhibitory concentrations of androgens up-regulate insulin-like growth factor binding protein-3 expression via an androgen response element in $\mathrm{LNCaP}$ human prostate cancer cells. Endocrinology. 2006;147:4599-4607.

101. Pandini G, Mineo R, Frasca F, et al. Androgens up-regulate the insulin-like growth factor-I receptor in prostate cancer cells. Cancer Res. 2005;65:1849-1857.

102. Tsuei DJ, Lee PH, Peng HY, et al. Male germ cell-specific RNA binding protein RBMY: a new oncogene explaining male predominance in liver cancer. PLoS One. 2011;6(11):e26948.

103. Rosini P, Bonaccorsi L, Baldi E, et al. Androgen receptor expression induces FGF2, FGF-binding protein production, and FGF2 release in prostate carcinoma cells: role of FGF2 in growth, survival, and androgen receptor down-modulation. Prostate. 2002;53(4):310-321.

104. Wu Y, Chhipa RR, Cheng J, Zhang H, Mohler JL, Ip C. Androgen receptor-mTOR crosstalk is regulated by testosterone availability: implication for prostate cancer cell survival. Anticancer Res. 2010;30(10):3895-3901

105. Wang SH, Yeh SH, Chen PJ. The driving circuit of HBx and androgen receptor in HBV-related hepatocarcinogenesis. Gut. 2014;63(11):1688-1689.

106. Wang SH, Chen PJ, Yeh SH. Gender disparity in chronic hepatitis B: mechanisms of sex hormones. J Gastroenterol Hepatol. 2015.

107. Yeh SH, Chen PJ. Gender disparity of hepatocellular carcinoma: the roles of sex hormones. Oncology. 2010;78 Suppl 1:172-179.

108. Groupe d'Etude et de Traitement du Carcinome Hépatocellulaire. Randomized trial of leuprorelin and flutamide in male patients with hepatocellular carcinoma treated with tamoxifen. Hepatology. 2004;40(6):1361-1369.

109. Chao Y, Chan WK, Huang YS, et al. Phase II study of flutamide in the treatment of hepatocellular carcinoma. Cancer. 1996;77(4):635-639.

110. Grimaldi C, Bleiberg H, Gay F, et al. Evaluation of antiandrogen therapy in unresectable hepatocellular carcinoma: results of a European Organization for Research and Treatment of Cancer multicentric double-blind trial. J Clin Oncol. 1998;16(2):411-417.

111. Forbes A, Wilkinson ML, Iqbal MJ, Johnson PJ, Williams R. Response to cyproterone acetate treatment in primary hepatocellular carcinoma is related to fall in free 5 alpha-dihydrotestosterone. Eur J Cancer Clin Oncol. 1987;23(11):1659-1664.

112. Gupta S, Korula J. Failure of ketoconazole as anti-androgen therapy in nonresectable primary hepatocellular carcinoma. J Clin Gastroenterol. 1988;10(6):651-654.

113. Guéchot J, Peigney N, Ballet F, Vaubourdolle M, Giboudeau J, Poupon R. Effect of D-tryptophan-6-luteinizing hormone-releasing hormone on the tumoral growth and plasma sex steroid levels in cirrhotic patients with hepatocellular carcinoma. Hepatology. 1989;10(3): 346-348.

114. Manesis EK, Giannoulis G, Zoumboulis P, Vafiadou I, Hadziyannis SJ. Treatment of hepatocellular carcinoma with combined suppression and inhibition of sex hormones: a randomized, controlled trial. Hepatology. 1995;21(6):1535-1542.

115. Falkson G, Ansell S. Phase II trial of buserelin in hepatocellular carcinoma. Eur J Cancer Clin Oncol. 1989;25(9):1339-1340.

116. Yu MW, Cheng SW, Lin MW, et al. Androgen-receptor gene CAG repeats, plasma testosterone levels, and risk of hepatitis B-related hepatocellular carcinoma. J Natl Cancer Inst. 2000;92(24):2023-2028.

117. Yu MW, Yang YC, Yang SY, et al. Hormonal markers and hepatitis $\mathrm{B}$ virus-related hepatocellular carcinoma risk: a nested case-control study among men. J Natl Cancer Inst. 2001;93(21):1644-1651.

118. Yu MW, Yang YC, Yang SY, et al. Androgen receptor exon 1 CAG repeat length and risk of hepatocellular carcinoma in women. Hepatology. 2002;36(1):156-163.

119. Yeh SH, Chang CF, Shau WY, et al. Dominance of functional androgen receptor allele with longer CAG repeat in hepatitis B virus-related female hepatocarcinogenesis. Cancer Res. 2002;62(15):4346-4351.

120. Yeh SH, Chiu CM, Chen CL, et al. Somatic mutations at the trinucleotide repeats of androgen receptor gene in male hepatocellular carcinoma. Int J Cancer. 2007;120(8):1610-1617. 
121. Zhu R, Zhang JS, Zhu YZ, et al. HBx-induced androgen receptor expression in HBV-associated hepatocarcinoma is independent of the methylation status of its promoter. Histol Histopathol. 2011;26:23-35.

122. Liu B, Wen X, Huang C, Wei Y. Unraveling the complexity of hepatitis B virus: from molecular understanding to therapeutic strategy in 50 years. Int J Biochem Cell Biol. 2013;45:1987-1996.

123. Yang WJ, Chang CJ, Yeh SH, et al. Hepatitis B virus X protein enhances the transcriptional activity of the androgen receptor through c-Src and glycogen synthase kinase-3beta kinase pathways. Hepatology. 2009;49(5):1515-1524.

124. Wang SH, Yeh SH, Lin WH, Wang HY, Chen DS, Chen PJ. Identification of androgen response elements in the enhancer I of hepatitis B virus: a mechanism for sex disparity in chronic hepatitis B. Hepatology. 2009;50(5):1392-1402.

125. Wu MH, Ma WL, Hsu CL, et al. Androgen receptor promotes hepatitis $B$ virus-induced hepatocarcinogenesis through modulation of hepatitis B virus RNA transcription. Sci Transl Med. 2010;2(32):32ra35.
126. Tian Y, Kuo CF, Chen WL, Ou JH. Enhancement of hepatitis B virus replication by androgen and its receptor in mice. $J$ Virol. 2012;86(4):1904-1910.

127. Yu Z, Gao YQ, Feng H, et al. Cell cycle-related kinase mediates viral-host signalling to promote hepatitis B virus-associated hepatocarcinogenesis. Gut. 2014;63(11):1793-1804.

128. Hogg K, Wood C, McNeilly AS, Duncan WC. The in utero programming effect of increased maternal androgens and a direct fetal intervention on liver and metabolic function in adult sheep. PLoS One. 2011;6(9):e24877.

129. Zhang H, Liu Y, Wang L, et al. Differential effects of estrogen/ androgen on the prevention of nonalcoholic fatty liver disease in the male rat. J Lipid Res. 2013;54(2):345-357.

130. Kelly DM, Nettleship JE, Akhtar S, et al. Testosterone suppresses the expression of regulatory enzymes of fatty acid synthesis and protects against hepatic steatosis in cholesterol-fed androgen deficient mice. Life Sci. 2014;109(2):95-103.

\section{Publish your work in this journal}

The Journal of Hepatocellular Carcinoma is an international, peerreviewed, open access journal that offers a platform for the dissemination and study of clinical, translational and basic research findings in this rapidly developing field. Development in areas including, but not limited to, epidemiology, vaccination, hepatitis therapy, pathology and

\section{Dovepress}

molecular tumor classification and prognostication are all considered for publication. The manuscript management system is completely online and includes a very quick and fair peer-review system, which is all easy to use. Visit http://www.dovepress.com/testimonialsphp to read real quotes from published authors.

\footnotetext{
Submit your manuscript here: http://www.dovepress.com/journal-of-hepatocellular-carcinoma-journal
} 